\title{
Evaluation of NDRG2 gene expression in primary papillary thyroid carcinoma and in metastases of this neoplasm to regional lymph nodes
}

\author{
Anna Mordalska ${ }^{1}$, Joanna Latek ${ }^{2}$, Tomasz Ferenc ${ }^{1}$, Lech Pomorski ${ }^{3}$ Elżbieta Gałecka ${ }^{4}$, Arkadiusz Zygmunt ${ }^{2,4}$, \\ Andrzej Lewiński ${ }^{2,4^{*}}$
}

\begin{abstract}
Background: At present, researchers' attention has been concentrating on NDRG2 (N-Myc downstream-regulated gene 2) as a new gene candidate in the development and progression of papillary thyroid carcinoma (PTC). NDRG2, together with NDRG1, NDRG3 and NDRG4 are members of the NDRG family, a new class of genes, inhibited by N-Myc oncogene.
\end{abstract}

Aim: The aim of our study was to evaluate NDRG2 mRNA expression in the primary PTC and its metastases to regional lymph nodes.

Materials and methods: Postoperative tissue and macroscopically changed lymph nodes of sixteen (16) patients with PTC constituted the studied material. In this group, metastases of the cancer to regional lymph nodes were confirmed histopathologically in 8 cases. Quantitative evaluation of NDRG2 mRNA expression was performed by the real-time polymerase chain reaction (real-time PCR) method.

Results: The mean values of NDRG2 mRNA expression in the primary tumour tissues were statistically significantly lower vs. the levels of NDRG2 mRNA expression in macroscopically unchanged thyroid tissue $(p<0.0001)$. A comparison of the mean NDRG2 mRNA expression of primary tumours and that of their metastases to regional lymph nodes did not demonstrate any statistical differences $(p>0.05)$. A positive correlation was observed between NDRG2 mRNA expression in primary tumour cells and in the cancer metastases to lymph nodes (Rs = 0.7857; $\mathrm{p}<0.05$ ). Factors, such as age, sex, tumour stage in TNM system, were of no significance for NDRG2 mRNA expression level $(p>0.1)$.

Conclusion: The results of our study demonstrated decreased NDRG2 mRNA expression levels in PTC, when compared to macroscopically unchanged thyroid tissue, which may point to the potential role of NDRG2 in the development and progression of cancer in question.

\section{Introduction}

Molecular disorders, associated with papillary thyroid carcinoma (PTC) development and progression, have for many years been and still are the subject of extensive and intensive research [1-4].

Currently, researchers' attention has been concentrating on NDRG2 (N-Myc downstream-regulated gene 2), a new candidate gene, taking part in the development and

\footnotetext{
* Correspondence: alewin@csk.umed.lodz.pl

${ }^{2}$ Department of Endocrinology and Metabolic Diseases, Polish Mother's

Memorial Hospital - Research Institute, Lodz, Poland

Full list of author information is available at the end of the article
}

progress of PTC. Deng et al. [5] were the first to have identified the human NDRG2 ( $N-M y c$ downstream-regulated gene 2). The to-date's data indicate a significant role of the $N D R G$ family in the proliferation and differentiation of cells. NDRG2 is localised on 14q11.2 chromosome and encodes a protein of $41 \mathrm{kDa}$ weight [6]. Studies of NDRG2 human gene expression at mRNA level have demonstrated the presence of a transcript of this gene in cells of the brain, the liver and the kidneys. The highest expression levels of the gene have been found in salivary glands, muscle and nervous cells, while NDRG2 mRNA was almost undetectable in the thymus, 
the bone marrow and leukocytes of peripheral blood. Such patterns of expression suggest a reverse correlation between the expression level of the gene and the cell proliferation rate [7]. A reduced NDRG2 gene expression has also been observed in a number of human neoplasms, which suggests its role as a suppressor gene of neoplasm [5,8-10].

It has been demonstrated that NDRG2 gene, in combination with TP53 gene, play a significant role in the process of apoptosis in response to DNA lesion, and $N D R G 2$ is an inhibitor of cellular proliferation, regardless of the status of TP53 in cell [11]. The human NDRG2 is inhibited by $M y c$ oncogene. The to-date's research has indicated that an increased expression of $M y c$ oncogene is associated with decreased NDRG2 gene expression in many neoplasms [12]. Studies, performed on neoplastic cell lines, have demonstrated that methylation of NDRG2 gene promoter and point mutations within the promoter in question cause a significant reduction of NDRG2 gene activity [8].

Up to date, only one study concerning the NDRG2 gene expression in papillary thyroid carcinoma has been published in the medical literature [13].

The goal of our study was an evaluation of mRNA expression of NDRG2 gene in primary PTC and in its metastases to regional lymph nodes.

\section{Materials and methods}

The procedures, as used in the study, had been approved by the Ethical Committee of the Medical University of Lodz, Poland.

Postoperative tissue samples and macroscopically changed lymph nodes of 16 patients with PTC constituted the study material. Out of them, neoplastic metastases to regional lymph nodes were histopathologically confirmed in 8 cases. The tumours were classified according to the World Health Organisation's Classification (TNM) [14]. Tissue samples were collected after total thyroidectomy, placed in storage buffer (RNA later RNA Stabilisation Reagent of Qiagen) (Hilden, Germany) and frozen in temperature of $-70^{\circ} \mathrm{C}$ until isolation of total RNA.

Selected clinical-pathological data of patients: age, sex, histopathological diagnosis and TNM classification (acc. to $\mathrm{WHO}$ ) are presented in Table 1.

\section{Isolation of total RNA and reverse transcription}

Total RNA was extracted from tissues, using an RNeasy Midi Kit (Qiagen, Hilden, Germany), according to the manufacturer's recommendations.

RNA concentration was spectrophotometrically assessed by measuring absorbance at 260 and $280 \mathrm{~nm}$.

Reverse transcription was performed in a personal Mastercycler (Eppendorf, Hamburg, Germany), using 1
Table 1 Selected clinical and pathological data of patients (age, gender), histopathological diagnosis, TNM classification (acc. to WHO)

\begin{tabular}{|c|c|c|c|c|}
\hline No: & Age & Gender & Diagnosis & Grade of progression in TNM scale \\
\hline 1. & 80 & $\mathrm{~F}$ & PTC & $\mathrm{pT}_{1} \mathrm{~N}_{0} \mathrm{M}_{0}$ \\
\hline 2. & 19 & $\mathrm{~F}$ & PTC & $\mathrm{pT}_{2} \mathrm{~N}_{1 \mathrm{~b}} \mathrm{M}_{0}$ \\
\hline 3. & 51 & $\mathrm{~F}$ & PTC & $\mathrm{pT}_{1} \mathrm{~N}_{1} \mathrm{M}_{0}$ \\
\hline 4. & 60 & M & PTC & $\mathrm{pT}_{1} \mathrm{~N}_{1 \mathrm{~b}} \mathrm{M}_{0}$ \\
\hline 5. & 72 & $\mathrm{~F}$ & PTC & $\mathrm{pT}_{4} \mathrm{~N}_{1} \mathrm{M}_{0}$ \\
\hline 6. & 55 & $\mathrm{~F}$ & PTC & $\mathrm{pT}_{1} \mathrm{~N}_{1} \mathrm{M}_{0}$ \\
\hline 7. & 42 & $\mathrm{~F}$ & PTC & $\mathrm{pT}_{1} \mathrm{~N}_{0} \mathrm{M}_{0}$ \\
\hline 8. & 58 & $\mathrm{~F}$ & PTC & $\mathrm{pT}_{1} \mathrm{~N}_{0} \mathrm{M}_{0}$ \\
\hline 9. & 33 & $\mathrm{~F}$ & PTC & $\mathrm{pT}_{1} \mathrm{~N}_{0} \mathrm{M}_{0}$ \\
\hline 10. & 50 & M & PTC & $\mathrm{pT}_{1} \mathrm{~N}_{0} \mathrm{M}_{0}$ \\
\hline 11. & 56 & M & PTC & $\mathrm{pT}_{4} \mathrm{~N}_{0} \mathrm{M}_{0}$ \\
\hline 12. & 48 & M & PTC & $\mathrm{pT}_{3} \mathrm{~N}_{0} \mathrm{M}_{0}$ \\
\hline 13. & 43 & $\mathrm{~F}$ & PTC & $\mathrm{pT}_{1} \mathrm{~N}_{1} \mathrm{M}_{0}$ \\
\hline 14. & 43 & $\mathrm{~F}$ & PTC & $\mathrm{pT}_{1} \mathrm{~N}_{1} \mathrm{M}_{0}$ \\
\hline 15. & 57 & $\mathrm{~F}$ & PTC & $\mathrm{pT}_{1} \mathrm{~N}_{\mathrm{x}} \mathrm{M}_{\mathrm{x}}$ \\
\hline 16. & 35 & $\mathrm{~F}$ & PTC & $\mathrm{pT}_{1} \mathrm{~N}_{1} \mathrm{M}_{0}$ \\
\hline
\end{tabular}

$\mu \mathrm{g}$ of total RNA in the presence of oligo d(T) $(50 \mu \mathrm{M})$ and MultiScribe ${ }^{\mathrm{rm}}$ Reverse Transcriptase $(50 \mathrm{U} / \mu \mathrm{l})$ in a total volume of $30 \mu \mathrm{l}$, including also: $10 \times$ TaqMan RT Buffer, $\mathrm{MgCl}_{2}$ solution ( $25 \mathrm{mM}$ ), dNTPs mixture $(10 \mathrm{nM})$, RNAse Inhibitor $(20 \mathrm{U} / \mu \mathrm{l})$ and nuclease-free water (TaqMan Reverse) Transcriptase Reagents, Applied Biosystems, Foster City, California, USA).

The reactions were incubated for 60 minutes at $27^{\circ} \mathrm{C}$, heated for 5 minutes to $95^{\circ} \mathrm{C}$ and then placed at $4^{\circ} \mathrm{C}$.

\section{Analysis of relative NDRG2 mRNA amount by real-time PCR}

An established Relative Qualification PCR assay for NDRG2 mRNA expression was used (in ABI PRISM 7500 Sequence Detection System, Applied Biosystems), according to the manufacturer's protocol. PCR reactions for NDRG2 were run with $50 \mathrm{ng}$ of cDNA in a total volume of $\mu \mathrm{l}$, using a TaqMan ${ }^{\text {TM }}$ Universal PCR Master Mix (Applied Biosystems, Foster City, California, USA) and the predesigned and labelled primer/probe set (Assay-on-Demand ${ }^{\mathrm{Tw}}$ Gene Expression assay mix Hs01045114_g1). After an initial, 2-minute incubation at $50^{\circ} \mathrm{C}$ to allow uracil-N-glycosylase digestion and at $95^{\circ} \mathrm{C}$ for 10 minutes to activate the Ampli Taq Gold ${ }^{\mathrm{m}} \mathrm{DNA}$ polymerase, both of which are provided by the Universal PCR Master Mix, the samples were amplified through 50 bi-phasic cycles of $95^{\circ} \mathrm{C}$ for $15 \mathrm{~s}$ and of $60^{\circ} \mathrm{C}$ for 1 minute.

Macroscopically unchanged thyroid tissue served as a calibrator. The amplification reactions were performed in triplicate for each sample. Controls with no template cDNA were used with each assay. 
The expression levels of glyceraldehyde-3-phosphate dehydrogenase gene $(G A P D H)$ were measured as endogenous controls (reference gene), using the appropriate Assay-on-Demand ${ }^{\mathrm{Tm}}$ Gene Expression Mix (Hs99999905_m1) (Foster City, California, USA).

Both gene expressions were measured for each tumour sample in the same PCR reaction but in separate wells.

The Assay-on-Demand Gene Expression Mix consists of $20 \times$ mix of unlabelled PCR primers $(18 \mu \mathrm{M}$ for each) and $\operatorname{TaqMan}^{\mathrm{Tm}}$ MGB probe $(5 \mu \mathrm{M})$ with $\mathrm{FAM}^{\mathrm{Tm}}(6-$ carboxy-fluorescein) at the 5' end as a reporter dye and a non-fluorescent quencher (TAMRA, 6-carboxy-tetramethylrhodamine) at the $3^{\prime}$ end. The two-minute, $50^{\circ} \mathrm{C}$ step is required for optimal AmpErase ${ }^{\mathrm{Tm}} \mathrm{UNG}$ activity, when TaqMan ${ }^{\text {TM }}$ Universal Master Mix is used.

Fluorescence signal was measured in real-time in the extension phase of the PCR reaction and the measurement, proportional to the quantity of sample cDNA in the reaction, was as an amplification curve against the cycle number. A threshold value of fluorescence in the exponential part of the amplification curve was selected and, for each sample, the number of cycles was measured, which is needed by the signal to reach the threshold (threshold cycle, $\mathrm{C}_{\mathrm{T}}$ ). The larger are the quantities of the starting material, the lower are $C_{T}$ values.

\section{Data analysis}

Data analysis was performed by means of the Taq-Man SDS analysis software (Applied Biosystems).

Fluorescence emission data were determined as $C_{T}$ values for each reaction and, for each sample, triplicate $\mathrm{C}_{\mathrm{T}}$ values were averaged. The average $\mathrm{C}_{\mathrm{T}}$ value for GAPDH was subtracted from the average NDRG2 $\mathrm{C}_{\mathrm{T}}$ value to yield $\Delta C_{\mathrm{T}}$ value to yield $\Delta \mathrm{C}_{\mathrm{T}}$ value. Normalisation to the reference gene $(G A P D H)$ was necessary to account for sample quantity and quality variations, as well as for the variations of PCR efficiency among particular samples. The assay, described in this report, involves $\Delta \Delta \mathrm{C}_{\mathrm{T}}$ value determination. This is calculated as: $\Delta \Delta \mathrm{C}_{\mathrm{T}}=\Delta \mathrm{C}_{\mathrm{T}}$ test sample $-\Delta \mathrm{C}_{\mathrm{T}}$ calibrator sample.

\section{Statistical analysis}

A non-parametric U-Mann-Whitney's test was used to compare the level of NDRG2 expression (RQ value) between the cancer tissue and the unchanged tissue. The Spearman's rank correlation coefficient was applied to determine the correlation between gene expression in PTC and in the metastasis of the carcinoma to lymph nodes. An assessment of relationships between the level of NDRG2 expression and such parameters, as patient's age, sex, tumour stage (acc. to TNM) was performed with the Spearmen's rank correlation coefficient (age, tumour stage) and U-Mann-Whitney test (sex). The results are presented as basic statistics for $R Q$ in particular groups. The statistical significance was set at $\mathrm{p}<0.05$.

Statistical analysis was performed by means of the Statistica (StatSoft, Windows 7.1) software package.

\section{Results}

The clinical and pathological data regarding the cases of PTC are shown in Table 1.

\section{Differential expression of NDRG2 mRNA in primary tumours and normal thyroid tissues}

Figure 1 presents the observed mean values of NDRG2 mRNA expression level in PTC cells $(n=16)$ and in normal thyroid tissue. The reference point for the studied gene expression in PTC tissue was the value from the averaging gene expression in macroscopically unchanged thyroid tissues. The mean values of NDRG2 mRNA expression level in primary carcinoma (tumour) cells were significantly lower vs. the of NDRG2 mRNA expression level in normal thyroid tissue $(\mathrm{p}<0.0001)$.

\section{NDRG2 mRNA expression in primary tumours and metastases}

Figure 2 presents the recorded mean values of the NDRG2 mRNA expression level in primary carcinoma (tumour) cells $(n=8)$ and the mean values of the NDRG2 mRNA expression level in metastases of the carcinoma to regional lymph nodes $(n=8)$. A comparison of the mean values of those parameters between the primary carcinoma (tumour) and metastases of that carcinoma to lymph nodes did not indicate any statistically significant differences $(p>0.05)$. There was no statistically significant difference $(\mathrm{p}>0.1)$ between the primary tumours with metastases and without metastases in regard to the NDRG2 mRNA expression.

A positive correlation was observed between the NDRG2 mRNA expression level in primary carcinoma (tumour) cells and the NDRG2 mRNA expression in the same carcinoma metastases to lymph nodes $(\mathrm{Rs}=$ $0.7857 ; \mathrm{p}<0.05)$. It means that the decrease of the NDRG2 mRNA expression level in primary carcinoma (tumour) was accompanied by a fall in the NDRG2 mRNA expression level in metastases of the carcinoma to lymph nodes.

\section{NDRG2 mRNA expression depending on tumour stage (TNM) and on patient's age and sex}

An evaluation of NDRG2 mRNA expression level, depending on tumour stage in TNM classification was performed for two groups: the first group included pT1 cases (Group pT1, $\mathrm{n}=12$ ) and the second one included (because of the small number) combined cases of pT2, pT3 and pT4 (Group pT2-pT4, n = 4) (Figure 3). A comparison of the mean values of NDRG2 mRNA 


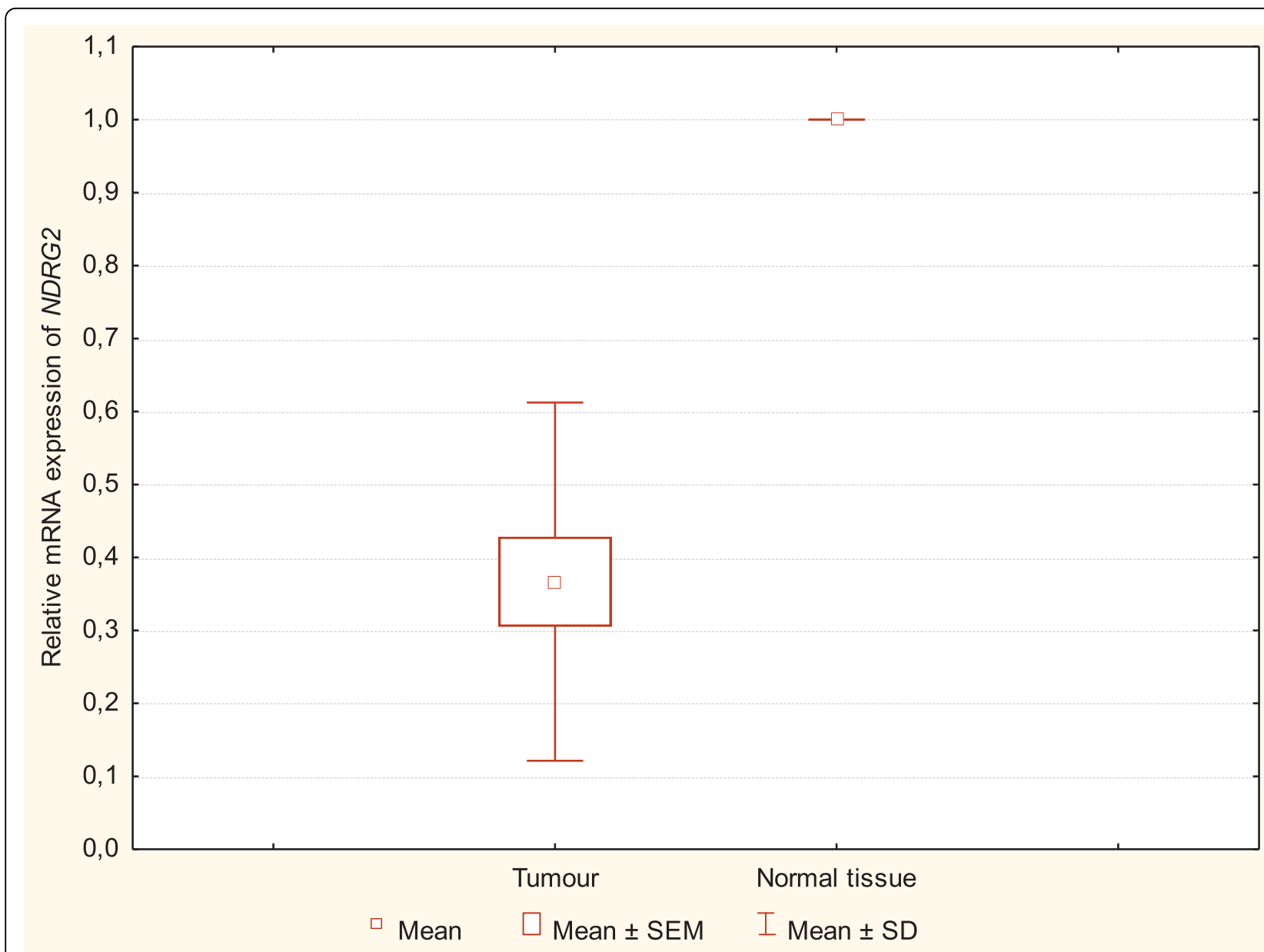

Figure 1 Box and whisker chart. The level of NDRG2 mRNA expression in macroscopically unchanged thyroid tissue and in PTC. The boxes represent means \pm SEM. The results obtained with U-Mann-Whitney's test point to a statistically significant difference of NDRG2 expression in the investigated groups $(p<0.0001)$

expression level between those two groups did not reveal any statistically significant differences $(\mathrm{p}>0.05)$.

An evaluation of the NDRG2 mRNA expression level, depending on patient age, was conducted in two groups: in the group of PTC cases in both sexes (primary tumour) at the age till $45(n=6)$ and in the group of cases at the age above $45(\mathrm{n}=10)$. The recorded mean values of NDRG2 mRNA expression level did not differ in any statistically significant way between those groups ( $p>0.05$ ). The calculated correlation coefficient did not show any significant relationship between the studied parameters for the age $(\mathrm{Rs}=0.0309 ; \mathrm{p}>0.1)$.

The mean values of NDRG2 mRNA expression level, recorded in the group of women $(n=12)$ and in the group of men $(n=4)$, did not show any statistically significant differences between those groups, either $(\mathrm{p}>0.1)$.

\section{Discussion}

Papillary thyroid carcinoma, despite usually good prognosis and low mortality rates, relatively frequently gives metastases to regional lymph nodes, while, more rarely, distant metastases (mainly to the lungs and bones). PTC spreads mainly via lymphatic vessels. Metastases to regional lymph nodes are observed in more than $50 \%$ of operated patients [15]. The most important prognostic factors in PTC include: age, sex, tumour size, encapsulation, infiltration of perithyroid tissues, metastases and postoperative thyroglobulin $(\mathrm{Tg})$ levels $[16,17]$.

In the reported study, the NDRG2 mRNA expression levels were evaluated in PTC and in its metastases to regional lymph nodes. In the study, we analysed postoperative tissue material, from primary carcinoma (tumour) and from macroscopically changed lymph nodes, collected from 16 patients of both sexes. 


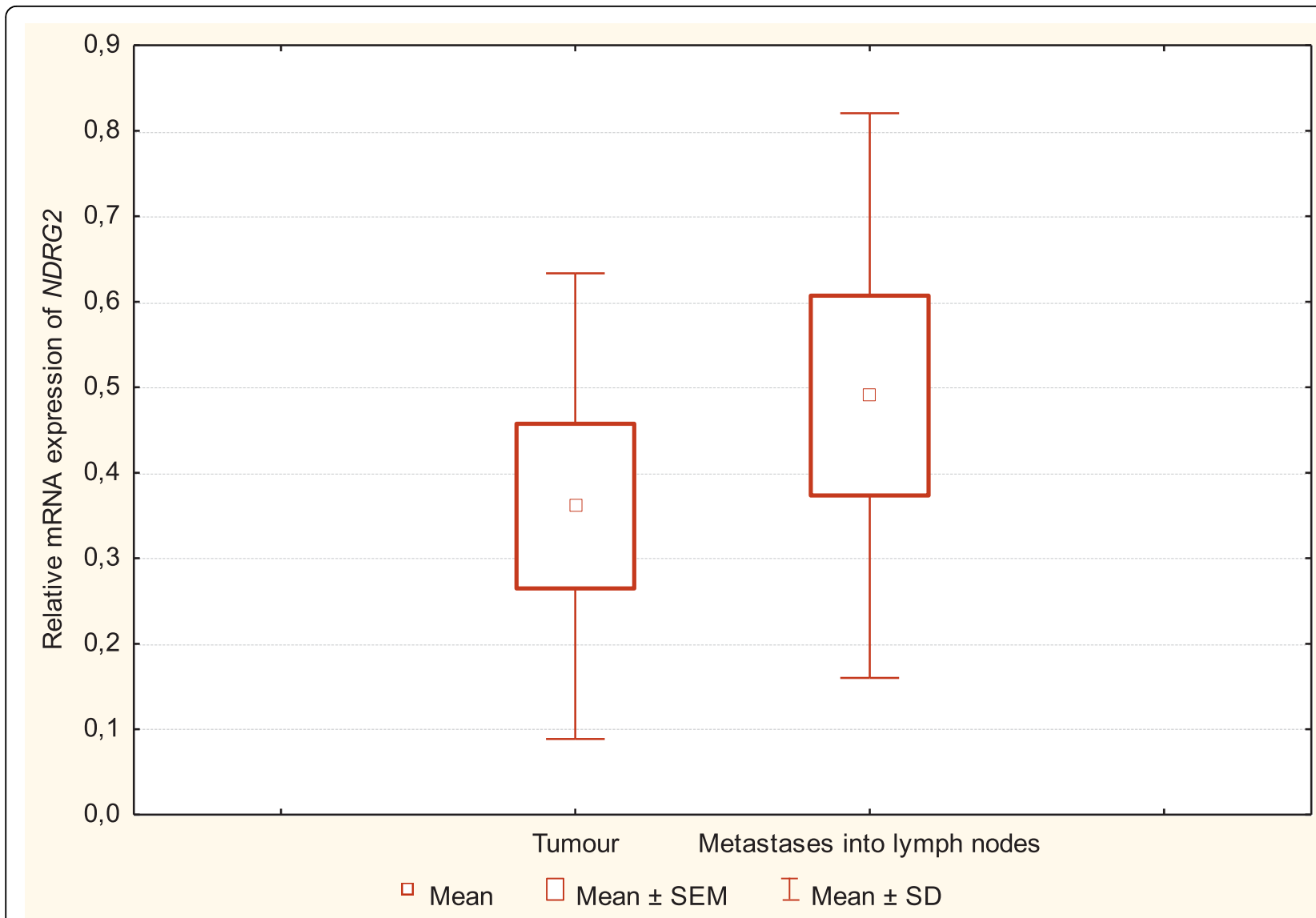

Figure 2 Box and whisker chart. The level of NDRG2 mRNA expression in primary tumour and in metastases to regional lymph nodes. The results obtained with Spearman's rank correlation test did not demonstrate statistically significant differences between the level of expression in the investigated groups ( $p>0.05$ ).

Histopathological analysis confirmed PTC presence in tumour tissue and - in 8 cases - metastases of the carcinoma to regional lymph nodes were identified.

Our present results have demonstrated a significantly reduced NDRG2 mRNA expression levels in cells of PTC ( $\mathrm{p}<0.0001)$. The recorded decrease of the NDRG2 mRNA expression level in primary carcinoma (tumour) tissue vs. that in macroscopically unchanged thyroid tissue, is in compliance with the results obtained by Zhao et al. [13]. Those authors have been - till now - the first who have published the results of studies on NDRG2 mRNA expression level in PTC. In the study by those authors, decreased NDRG2 gene expression levels were found in all the studied cases of PTC $(n=53)$ [13].

The results of our study confirm also the reports of other authors, analysing the NDRG2 gene expression level in various neoplasms [5,6,8-10]. Deng et al. [5] analysed NDRG2 gene mRNA levels in cells of glioma and in normal brain tissues. The results of these authors revealed decreased NDRG2 expression in approximately $60 \%$ of gliomas vs. the expression levels in normal brain tissue. Lusis et al. [8] noted that the expression of $N D R G 2$ in glioma was reduced at transcript and protein level. In studies of Norwegian authors, it was demonstrated that mRNA level of NDRG2 gene was significantly lower in colon cancer tissue than in normal tissues [10]. Also studies of NDRG2 gene expression in gastric carcinoma revealed decreased expression levels of the gene in some of the patients [18]. Moreover, the authors suggested that studies of NDRG2 gene expression could be used as a prognostic factor for the survival rate of patients with gastric carcinoma. In the group with decreased expression of NDRG2 gene, the survival rate of patients was significantly lower [18].

Other groups of researchers also described decreased expression of NDRG2 gene in tissues from various malignant neoplasms, e.g., in breast cancer [19], liver carcinoma [20], clear cell renal carcinoma [21] and skin carcinoma [22].

The process of neoplastic cell metastasis formation includes an intricate complex of molecular and biochemical events ("metastatic cascade"), including: the 


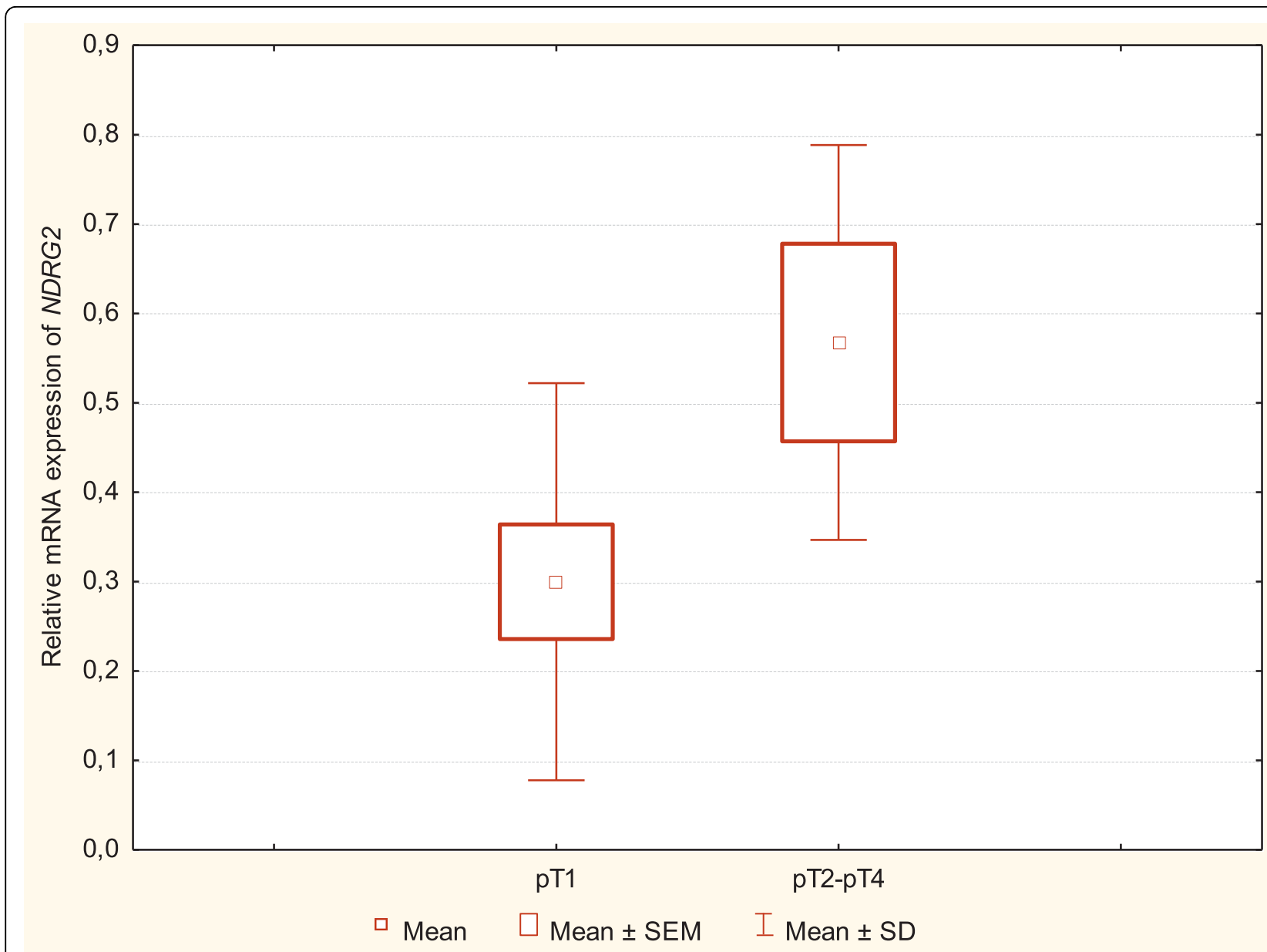

Figure 3 Box and whisker chart. The dependence of the level of NDRG2 mRNA expression on the tumour grade ( $p T$, TNM scale) in two investigated PTC groups: PT1 $(n=10)$ and PT2-pT4 $(n=4)$. The boxes represent means \pm SEM. The results were obtained with Spearman's rank correlation test $(p>0.05)$.

invasion of primary tumour cells to surrounding tissues, angioinvasion, migration, reimplantation and proliferation of cells. One of the groups of the genes, which participate in these processes, are suppressor genes in the mechanism of metastasis formation, e.g., nm23, Kai1, KISS1 [23]. During recent years, also NDRG2 gene has been added to the group [7].

In our studies, we found no differences between NDRG2 mRNA expression level in primary PTC and mRNA expressions levels in metastases of the carcinoma to regional lymph nodes. However, a positive correlation was noted between NDRG2 mRNA expression levels in primary PTC cells and the expression levels of NDRG2 mRNA in metastases of the carcinoma to lymph nodes, what means that the decrease of the NDRG2 mRNA expression level in the primary PTC was accompanied by decreased mRNA expression levels of NDRG2 gene in metastases of the carcinoma to lymph nodes. The results of our study are similar to the results obtained by Zhao et al. [13].

In the present study, we have not defined the role of NDRG2 in PTC metastases to lymph nodes; that problem requires further analyses in subsequent studies performed on higher numbers of cases.

In our studies, the prevailing number of cases with PTC $(\mathrm{n}=12)$ was qualified to pT1 group in TNM classification. The other, individual cases of PTC, qualified to pT2, pT3 and pT4, were included into other separate group $(n=4)$.

A comparison of NDRG2 gene expression in the two studied groups of patients with various degree of tumour progression, i.e., in Group pT1 and in Group pT2-pT4, did no show any statistically significant difference. Interestingly, no correlation was documented in the study of Zhao et al. between the expression of $N D R G 2$ gene and thyroid tumour size [13]. 
We also evaluated the correlation between the expression of NDRG2 gene and patient's age. We have divided the study group into two subgroups: the age till $45(\mathrm{n}=$ $6)$ and above $45(n=10)$. However, an analysis of the correlation between the expression of NDRG2 mRNA and the age of examined patients did not show any statistically significant differences. In other reports on different types of neoplasms, including PTC, no correlation was shown between the expression of NDRG2 gene and patients' age $[10,22]$. Moreover, no correlation between the expression of NDRG2 and patient's sex, was demonstrated in our study.

\section{Conclusions}

In conclusion, the results of our study demonstrated a decreased level of NDRG2 gene expression in PTC vs. macroscopically unchanged thyroid tissue, what may indicate a potential role of NDRG2 gene in the development and progression of this neoplasm. No correlations were found between the expression of NDRG2 gene and patient's sex or age or the degree in tumour staging (TNM) or its metastases. The evident lack of satisfactory literature data, regarding the studies of NDRG2 gene expression in PTC is an encouragement to undertake further studies on a larger groups of patients, which may enable to evaluate the potential of NDRG2 gene as a biological marker in PTC.

\section{Acknowledgements}

This study was supported by funds for realisation of Project No. 502-17-657 from the Medical University of Lodz, Lodz, Poland.

\section{Author details \\ 'Department of Biology and Medical Genetics, Medical University of Lodz, Lodz, Poland. 'Department of Endocrinology and Metabolic Diseases, Polish Mother's Memorial Hospital - Research Institute, Lodz, Poland. ${ }^{3}$ Department of General and Oncological Surgery, Medical University of Lodz, Zgierz, Poland. ${ }^{4}$ Department of Endocrinology and Metabolic Diseases, Medical University of Lodz, Lodz, Poland.}

\section{Authors' contributions}

AM designed and coordinated the study, carried out the molecular genetic studies and drafted the manuscript. JL participated in performing molecular studies. TF participated in coordination of the study. LP participated in the design of the study. AZ participated in coordination of the study. EG participated in performing molecular studies. AL, the senior author, conceived of the study and wrote the manuscript. All authors have read and approved the final manuscript.

\section{Competing interests}

The authors declare that they have no competing interests.

Received: 8 July 2010 Accepted: 30 August 2010

Published: 30 August 2010

\section{References}

1. Adeniran AJ, Zhu Z, Gandhi M, Steward DL, Fidler JP, Giordano TJ, Biddinger PW, Nikiforov YE: Correlation between genetic alterations and microscopic features, clinical manifestations, and prognostic characteristics of thyroid papillary carcinomas. Am J Surg Pathol 2006, 30:216-222.

2. Nikiforov Y: Thyroid carcinoma: molecular pathways and therapeutic targets. Mod Pathol 2008, Suppl 2: S37-S43.

3. Sherman SI: Thyroid carcinoma. Lancet 2003, 361:501-511.

4. Lewiński A, Ferenc T, Sporny S, Jarząb B: Thyroid carcinoma: diagnostic nad therpeutic approach; genetic background (review). Endocrine Regul 2000, 34:99-113.

5. Deng Y, Yao L, Chau L, Ng SS, Peng Y, Liu X, Au WS, Wang J, Li F, Ji S, Han H, Nie X, Li Q, Kung HF, Leung SY, Lin MC: N-Myc downstreamregulated gene 2 (NDRG2) inhibits glioblastoma cell proliferation. Int J Cancer 2003, 106:342-347.

6. Yao L, Zhang J, Liu X: NDRG2: aa Myc-repressed gene involved in cancer and cell stress. Acta Biochim Biophys Sin 2008, 40:625-635.

7. Qu X, Zhai Y, Wei H, Zhang C, Xing G, Yu Y, He F: Characterization and expression of three novel differentiation-related genes belong to the human NDRG gene family. Mol Cell Biochem 2002, 229:35-44.

8. Liu N, Wang L, Liu X, Yang Q, Zhang J, Zhang W, Wu Y, Shen L, Zhang Y, Han H, Zhang J, Yao L: Promoter methylation, mutation, and genomic deletion are involved in the decreased NDRG2 expression levels in several cancer cell lines. Biochem Biophys Res Commun 2007, 358:164-169.

9. Lusis EA, Watson MA, Chicoine MR, Lyman M, Roerig P, Reifenberger G, Gutmann DH, Perry A: Integrative genomic analysis identifies NDRG2 gene as a candidate tumor suppressor gene frequently inactivated in clinically aggressive meningioma. Cancer Res 2005, 65:7121-7126.

10. Lorentzen A, Vogel LK, Lewinsky RH, Sæbø M, Skjelbred CF, Godiksen S, Hoff G, Tveit KM, Lothe IM, Ikdahl T, Kure EH, Mitchelmore C: Expression of NDRG2 is down-regulated in high-risk adenomas and colorectal carcinoma. BMC Cancer 2007, 7:192-198.

11. Liu N, Wang L, Li X, Yang Q, Liu X, Zhang J, Wu Y, Ji S, Zhang Y, Yang A,

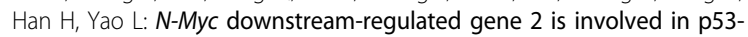
mediated apoptosis. Nucleic Acids Res 2008, 36:5335-5349.

12. Hoffman B, Liebermann DA: Apoptotic signaling by c-MYC. Oncogene 2008, 27:6462-6472.

13. Zhao H, Zhang J, Lu J, He X, Chen C, Li X, Gong L, Bao G, Fu Q, Lin W, Shi H, Ma J, Liu X, Ma Q, Yao L: Reduced expression of N-Myc downstream-regulated gene 2 in human thyroid cancer. BMC Cancer 2008, 8:303-311.

14. DeLellis RA, Lloyd RV, Heitz PU, Eng C: World Health Organization. Classification of tumours. Pathology and genetics of tumours of endocrine organs. IARC Press, Lyon 2004.

15. Hunt JL, LiVolsi VA, Baloch ZW, Barnes EL, Swalsky PA, Niehouse L, Finkelstein SD: Microscopic papillary thyroid carcinoma compared with clinical carcinomas by loss heterozygosity mutational profile. Am J Surg Pathol 2003, 27:159-166.

16. Lin JD, Chen ST, Chao TC, Hsueh C, Weng HF: Diagnosis and therapeutic strategy for papillary thyroid microcarcinoma. Arch Surg 2005, 140:940-945

17. Ito Y, Masuoka H, Fukushima M, Inoue H, Kihara M, Tomoda C, Higashiyama T, Takamura Y, Kobayashi K, Miya A, Miyauchi A: Prognosis and prognostic factors of patients with papillary carcinoma showing distant metastasis at surgery (M1 patients) in Japan. Endocr J 2010, 57:523-531.

18. Choi SC, Yoon SR, Park YP, Song EY, Kim JW, Kim WH, Yang Y, Lim JS, Lee HG: Expression of NDRG2 is related to tumor progression and survival of gastric cancer patients through Fas-mediated cell death. Exp Mol Med 2007, 39:705-714.

19. Stark AM, Tongers K, Mehdorn HM, Held-Feindt J: Reduced metastasissupressor gene mRNA-expression in breast cancer metastases. $J$ Cancer Res Clin Oncol 2005, 131:191-198.

20. Hu XL, Liu XP, Lin SX, Deng YC, Liu N, Li X, Yao LB: NDRG2 expression and mutation in human liver and pancreatic cancers. World J Gastroenterol 2004, 10:3518-3521.

21. Ma J, Jin H, Wang H, Yuan J, Bao T, Jiang X, Zhang W, Zhao H, Yao L: Expression of NDRG2 in clear cell renal cell carcinoma. Biol Pharm Bull 2008, 31:1316-1320.

22. Hummerich L, Müller R, Hess J, Kokocinski F, Hahn M, Fürstenberger G, Mauch C, Lichter P, Angel P: Identification of novel tumour-associated 
genes differentially expressed in the process of squamous cell cancer development. Oncogene 2006, 25:111-121.

23. Stark AM, Tongers K, Mehdorn HM, Held-Feindt J: Reduced metastasissupressor gene mRNA-expression in breast cancer brain metastases. $J$ Cancer Res Clin Oncol 2005, 131:191-198.

doi:10.1186/1756-6614-3-6

Cite this article as: Mordalska et al.: Evaluation of NDRG2 gene

expression in primary papillary thyroid carcinoma and in metastases of this neoplasm to regional lymph nodes. Thyroid Research 2010 3:6.

Submit your next manuscript to BioMed Central and take full advantage of:

- Convenient online submission

- Thorough peer review

- No space constraints or color figure charges

- Immediate publication on acceptance

- Inclusion in PubMed, CAS, Scopus and Google Scholar

- Research which is freely available for redistribution

Submit your manuscript at www.biomedcentral.com/submit
C Biomed Central 